\title{
Values Implied in the Wratisasana Palm Manuscripts as Guideline of Politeness in Language of the Character Education: A Study of Theo-Ethno Pedagogy
}

\author{
Relin \\ Institut Hindu Dharma Negeri, Denpasar, Indonesia \\ I Wayan Rasna \\ Universitas Pendidikan Ganesha, Bali, Indonesia \\ W.S. Binawati \\ Institut Hindu Dharma Negeri, Denpasar, Indonesia
}

\begin{abstract}
This study is aimed at clear descriptions of 1) the values of Wratisasana manuscript as character education guideline and 2) the advantage of Wratisasana educational values. The objects of this study are Wratisasana Palm Manuscripts. The main informants are Drs. I Ketut Dalem, M.Ag., and Drs. I Gede Sura, M.Si. Samples of this study were taken from some manuscripts and the main informants. The study applied qualitative research. The data were collected by using documentation method especially interview technique. The data obtained were analysed descriptively. Some findings from the analysis are 1) values in Wratisasana manuscript are (1) compassion, (2) faith and religiosity, (3) pedagogical value, (4) honesty, (5) politeness, (6) discipline, (7) responsibility, (8) tolerance, and (9) basic foundations of life; 2) the relevant values are peace loving, fond of reading and responsible being. Based on the findings it can be concluded that the educational values in Wratisasana manuscript are 1) compassion, 2) religiosity, 3) pedagogical value, 4) honesty, 5) politeness, 6) responsible being, 7) tolerance and foundation of life. The applicable values into character education namely (1) religiosity, (2) honesty, (3) tolerance, (4) discipline, (5) hard working, (6) friendliness, (7) love for peace, $(8)$ fond of reading, and (9) responsibility. The conclusions lead to a recommendation to use the teaching of Wratisasana manuscript as one of references for character education in this case for teaching the students about politeness in language.
\end{abstract}

Index Terms-politeness, character education, Wratisasana manuscript, Theo-Ethnopedagogy

\section{INTRODUCTION}

Wratisasana manuscript contains teachings for people who practice wrata or brata i.e. a living-vow according to the religion. The follower of this teaching has to learn as a student who is taught by the teacher, a child who is taught by the parents. To be a good person, a child has to be taught properly by the parents, teachers and communities. One who does not teach his child must be put into hell (Suardanayasa, et.al. 2006, p.3). Wratisasana is important not only to lead a priest but also important to the educational world (Rasna, 2016: 2) because Wratisasana teaches: 1) critical way of thinking, 2) nonviolence, 3) anticorruption, 4) peace education, 5) multicultural living, and 6) literary intelligence (Sojomukti, 2015, pp.39-106). Therefore, any kinds of learning including language learning is not merely about phoneme, word, phrase, sentence and discourse, but furthermore, it is continued to learn the meaning and message behind the words and sentences that cannot be separated with the ethical aspects (Jendra, 2009, p. 1). Ethics is a value which is related to behaviour (Moeliono, 1988, p. 237). Speaking ethics is understood as a knowledge and moral indicators of speaking (Favler and Fowler, 1964, p.415 in Jendra, 2009 p. 11).

An excellent educated person who has no equal behaviour and speaking ethics should be doubt that he gets positive advantages of his owned knowledge. This is because one who has high education should have a noble character (Khandwa, 1992. pp.54-55 and Pudja, 1985, pp.45-47). One, who speaks gentle, in order and polite, is considered having a good way of reasoning and intellectuality (Jendra, 2009, p.14). These statements confirmed there is a relationship between thought and speaking (Crystal 1992, p.14 and Su'ud, 1990, pp.32-34). The two aspects are inseparable relationship in dealing with the language functions. Some scholars mention about language functions among them, Malinowski, who divided language functions into two. The others, who divided language functions into three, are Sudaryanto (1990), Buhler (1934) Revesz and Halliday (1977). Besides, there are scholars who divided language functions into four, Ogden and Richard and into five functions, namely, Leech (in Sudaryanto, 1990, p. 921), and even into six functions like Jacobson (in Teeuw, 1984, p. 54). 
Language function is mentioned in Wratisasana. One of the language functions is as the language for ritual activities, a means of communication in religious ceremony (Malinowski in Sibarani, 2004, p. 44). Cassirer (1987, pp. 168-169) stated that language is a word that has a magical power (Dhavamony, 1995: 58-59). And the role of spoken language is as a religio-spiritual media (Kasturi, 1985; 1987). The ethics of language use are related with the speaker's attitude and behaviour during the time of speaking.

The ethics of language use, which are related with the speaker's attitude and behaviour, are also related with culture. A speaker has to conduct speaking activities by paying attention on the local customs and culture. Human being is a subject in a society (Bakker, 1988, p. 27 and Casson, 1981, p. 17). Human being has agreed on a language as a part of cultural forms. Language is a result of culture is a symbol of meaning, which is created to fulfill the needs of communication in politeness order (Ahimsa Putra, 2001, p.24). Polite communication reflected the well grown-up character of human being (Mantra, 1997, p.17). In order to achieve the performance, family has an important role to pay attention on the process of psycho-reality forming (way of reasoning, way of feeling and the impacts of behaviour) in every child as the members of a family, which is affecting the whole way of behaviour in his/her entire life (Waruwu, 2010, p. 38). Way of behaviour is influenced by the way of life (Nashir, 2013, p. 64). The way of life is related to the concept of values which control the harmony as implied in the Tri Hita Karana, three causes of prosperity (Suryawan, 2017, p. 23).

The ethics of talk is one aspect that is taught in the Wratisasana, i.e. awyawaharika (peaceful and wholehearted). The practice of awyawaharika as one of Wratisasana teaching is the implementation of the ethics of talk (linguistic ethics). Thus, ethics is niti karma, an attitude or conduct. This indicates the daily activities should be according to the politeness, norms or ethics, including language performance, according to the Wratisasana teaching. The language performance is related to the value of righteousness and wickedness, and also goodness and badness in human living (Graham, 2016, p.1). Human life has been processing since a growing seed in a womb, birth, toddler period, childhood, growing up, adolescence, elderly, until the moment one must go back to the eternal life. One cannot avoid the learning process to be adaptable in the social living. During the learning process, ethics is important knowledge according to psychological research that prepared a set of sources to help teachers' job to conduct an effective learning process (Khodijah, 2016, p. 21). The learning process is effective if children can make decision effectively and wisely, and can execute the decision in their daily life so that they could give positive contribution to the whole environment (Megawangi, 2004, p. 95; Kesuma, 2011, p. 5).

Linguistics behaviour is part of Wratisasana. It generally refers to the Tatwa (Jnana, philosophy). Politeness of linguistics behaviour can be the reflection of the philosophical awareness and comprehension (Tatwa). The way of thinking, conducting, making decision, behaving in every day, and the way of getting dressed is the reflection of the ethical awareness, and obviously the quality of one's understanding of the Wratisasana indirectly. This indicates the Wratisasana is the way of life that leads morally as the part of character education. This statement is on the same idea as stated by Samani and Hariyanto, as quoted from "Kerusakan Moral Mencemaskan" (The Alarm of Moral Destruction) in a newspaper, KOMPAS, Monday, 20 June 2011. This was the headline on the first page, the contents were:

- Along 2004 - 2011 the Ministry of Domestic Affairs has recorded 158 local leaders consisting of governors, regents, and majors got caught because of committing corruption

- At least 42 legislative parliament members got caught in between $2008-2011$

- 30 legislative parliament members in the period of $1999-2004$ from four political parties were involved in bribery for the election of the Senior Deputy Governor of the Indonesian Bank.

- Some corruption cases happened in several institutions such as electional governmental commission like KPU and KPPU, Judicial Commission, General Directorate of Taxation, The Indonesian Bank, and BK PM (Samani and Haryanto, 2012: 4).

It must be a sincere notification that according to the national culture, this kind of behaviour is in opposite with the moral value. If one refuses a perspective about moral attitude or a certain action, it was not denied that argumentations were indeed useful to convince the opposition. But we are not trying to show by our argument that our opposite had a wrong moral perspective upon the situation that basically was already understood. The think to be shown was that the opposite was wrong about the facts of that cases. We argued that there was a misunderstanding about the motivation of the agent or there was a misinterpretation about the action result or the result possibility by observing the knowledge of the doer, or one was not concerning specific situations on the existence of the agent.

The result of action or the possibility happen is reward and punishment for the committed actions. These have been happening since long ago (Walgito, 2011, p. 33). The reward or punishment is ideas, emotions and behaviours, which are influenced by the other existence, both the real and imaginative existence, or by the demanding of social roles (Allport, 1954, in Rahman, 2014, p. 5). This is according to the behaviorism, which is basic on the reality that human being is nor carrying the psychological genetics since born. This is because the human being evolves and indicates his or her own psychological aspects based on the recepted stimulus from the environment (Anwar, 2017, p. 15).

It is important to know that the behavior is the manifestation or the implementation of psychological conditions, but it does not indicate that the same psychological condition would result the same the same behaviour, such as two persons, who are angry, they are not always showing the same behaviors. There is a possibility of showing an impolite linguistics actions, like showing a grasp hand, violence expressions for instance: facial expression and tend to break or 
hit things around him or her as the object of releasing their agony. But perhaps the other is only stay in the silence while angry (Khodijah, 2016, p. 6). This is one of behavioural formulations. The other formulation is as mentioned by Bandura in Khodijah with the formulation: $B=F(E, O)$. ' $B$ ' stands for behaviour, ' $F$ ' stands for function, ' $E$ ' stands for environment and ' $\mathrm{O}$ ' stands for organism.

Basically, the formulation is not different from the other formulations, i.e. that the behaviour depends on the environment and the organism as well. But the relations between the ' $E$ ' and ' $O$ ' has not clearly shown. In order to make the relation more clearl, Bandura explains the formulations $\mathrm{B}=\mathrm{F}(\mathrm{E} \leftrightarrow \mathrm{O})$, i.e. the behaviour depends on the interaction between the enviroment and the organisms. The interaction is the reciprocal relations between the environment and the organisms. However, Bandura assumed the behaviour, environment and organisms influenced one another (Khodijah, 2016, p.7). Related to this matter, the character education, which is based on religion and culture, is necessary to conduct (Nashir, 2013: pp.21-40). Religion through the teaching texts and the roles of the follower have relationship with the national-living. The meant teaching texts is the Wratisasana. The unification of religion and the followers' life required an internalization, i.e. the comprehension and implementation of the whole teaching into the all aspects of the followers. However, the religion integration with the followers by the values internalization always has the dynamic aspects between the immanent and transcendent so that emerge the complex variations (Abdullah, 1974, p. 8).

Internalization of the religious value has the important value in mentoring human behavior. Religious value is a character value in the relationship with God. He is showing that thought, speech and action are always encouraged based on Theological and religious teachings (Mustari, 2014, p. 1).

This is important when we are facing the social-ethics crisis among children, teenagers, and even adults, such as the 'vail' generations as the result of giving high concentration to some games, gadget, short messages services and social media such as facebook, twitter, whatsapp and etc. have been degrading their morality. The ethics of greetings has been weakening. Some proves of this phenomena are ignoring people, impolite way of speaking, blasphemy, hoax on social media. This behavior becomes people attention (Idi and Safarma, 2015, p. V). However, to improve the situation is not easy. A mistake of handling the situation would emerge conflicts.

Problem solving especially for problems among teachers and students, professor and graduate students, a teacher has to comprehend: 1) educating a soul (students-graduate students), which includes the identities, characteristic and the actual problem. There is a possibility that they are committing forbidden actions according to the religion. They would be glad if there is somebody can understand their feeling. They would show sympathy to those who also feel what they are suffering. If the sympathy already exist in them, they would be easier to accept input and advice from others (Idi and Safania, 2015, p. 50). As much as possible there must be special attention for people with emotional imbalance. (Daradjat, 2005, pp. 13-15).

Emotional-imbalance that is happening to a person needs: 1) understanding with affection according to the Wratisasana; 2) educating through pedagogical values as implied in the values in the Wratisasana manuscripts. Religious approach like it is reflected in the Wratisasana, religious approach like the principal of Wratisasana manuscript as the religious teaching that guide the followers to conduct according to what is taught by the religion namely creed, piety, honesty, politeness, discipline, responsibility, and tolerance. The affection value of Wratisasana is applied as the reference for the character education to teach children since younger age about the importance of tolerance, giving affection one another, caring one another. This country consists of ethnics, religions, languages and culture. Multiethnic, multicultural and Multilanguage society deserves to educate their people the affection value since the younger age so that their mind and heart absorb the seed of fraternity through controlling the austerity of speech, respecting others and obeying rules (Idi and Safarina, 2015, p. 65).

Value of creed and piety has a very important role in implanting belief of the creed religion. Through this belief, the expected result is righteous and religious people. Pedagogical value through politeness in speech act would give a positive contribution and significant to the character education, reading, fond of reading, and speaking fluency. Fond of reading would open the children's mind to know more, to understand, to comprehend not only the cognitive and affective but also the psychomotor. The widen of cognitive skill would lead children to cultured their feeling. The cultured feeling has to be naturally accustomed by giving example by their parents at home and by their teacher in school, public figure in the society and stake holders. Everybody must in a sinergy. The cultured emotion is necessary so that children become sensitive and care with their environment. The cultured psychomotor would increase students skill. if the three things are run in a balance way, the expected situation is a conducive environment would be preserved. It is because of the education value in Wratisasana palm leave manuscript is not only important for the wikus (the leader of ceremony) but also it is important to the educational world generally, and specifically, the character education.

\section{MethodS}

There are two populations in this research namely, palm manuscripts and experts populations. There are collections of palm manuscripts in Gedong Kirtya, Pusdok and Badan Perpustakaan dan Arsip Pemprov.Bali. The experts are some persons having capability of explaining about palm manuscripts. Based on the populations, some samples were conducted purposively so that Wratisasana manuscript was chosen. The samples are selected based on the experts' populations, experiences, credibility and accountability. Having realized there are limited lontar manuscripts experts, 
the existing populations cannot be selected further. So, it is decided to treat the experts as samples. The research design is descriptive, which is documented on educational values implied in Wratisasana manuscripts and which analyze the values to develop character education.

The data, which are educational values in Wratisasana, were collected by using documentation technique. Besides, the supporting data were obtained from some experts by using deep-interview technique. All data collections were analyzed in descriptive-qualitative procedures.

\section{RESEARCH ANALYSIS AND ReSULTS}

\section{A. Educational Values in Wratisasana Palm Manuscript}

From educational point of view, there are nine values implied in the Wratisasana palm manuscript as mentioned on the following quote and the translation.

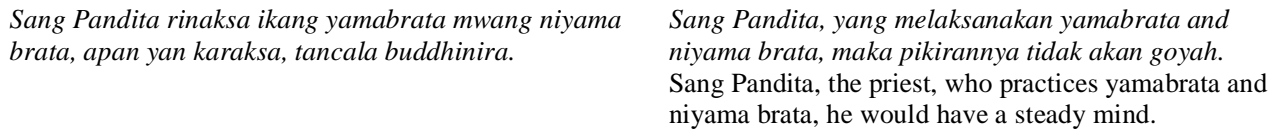

If this teaching is implemented by someone, he would have a firm mind. This sentence means that a strength and a firm mind to practice the righteous-teaching would have the nice result because by doing the Panca Yama Brata, which consists of ahimsa (nonviolence toward all living things), satya (truthful), awyawaharika (peaceful and whole-hearted), astaiya (non-stealing), brahmacharya (virtue of celibacy), and to practice Panca Niyama Brata teaching, namely, akroda (having no anger), guru susrusa (respecting teachers), sauca (clearliness and purity), aharalaghawa (eating rightly), apramada (watchfulness and awakeness), so that the ultimate affection happens. The practice of ahimsa comprises of many values among them love and tolerance.

The practices above indicate that literature as text contains cultural values (Gural, et. al., 2004, p. 436). Literary studies have been enhanced (Grixti, 2009). The studies indicate that learning has been conducted in a lifelong duration for all levels of society (Ruaire and Precey, 2013, p. 10). A literary work like Wratisasana gives many advantages to the students especially to create a noble character (Mustika, 2011, p. 59).

The practice of Ahimsa, nonviolence toward all living things, is a real formation of the application of character education in this case, the loving character. The practice of satya, truthful, is the realization of an honest character as a representation of anticorruption. The practice of awyawaharika, peaceful and whole-hearted, reflects the 'peace maker' character. Brahmacharya, virtue of celibacy, reflects a character of pedagogical values. Based on those practice of teaching, it can be stated that the values of wratisasana is one of character education sources, a value of pedagogy that is mentioned in the following quote.

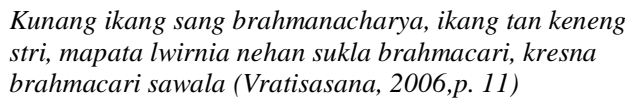

stri, mapata lwirnia nehan sukla brahmacari, kresna brahmacari sawala (Vratisasana, 2006,p. 11)

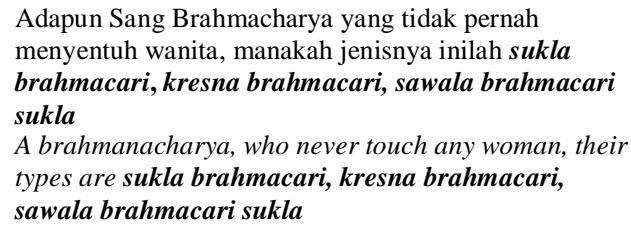

Adapun Sang Brahmacharya yang tidak pernah menyentuh wanita, manakah jenisnya inilah sukla brahmacari, kresna brahmacari, sawala brahmacari sukla

A brahmanacharya, who never touch any woman, their types are sukla brahmacari, kresna brahmacari, sawala brahmacari sukla

This value is a literary value of pedagogic (Jendra, 2016, p. 130). It is suitable with the purposes of education. One of the purposes is to lead students. By doing so, they could learn in high concentration so that they could achieve the maximum result. If one cannot fully concentrate during learning, the expected result cannot be in an optimal stage as well. Learning needs concentration. In order to be able to concentrate, a practice to be conduct is brahmacharya, 'celibate'.

The values of truthful is a behaviour that is based on the effort to make the self always be a reliable person in his thought, in his words and in his actions as well (Rasna, 2016, p. 29). This is reflected in the following quote of Wratisasana.

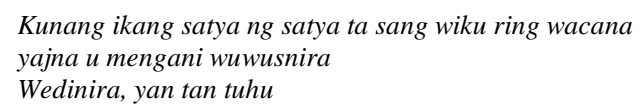

The word 'unright' emerges another problem. Also, the word 'rude', like a quote in the following Wratisasana. 


\begin{tabular}{|l|l|}
\hline Hawya wak parusya & Jangan berkata kasar \\
Asing ujar menak juga wusakina & Kata-kata yang baik saja hendaknya diucapkan \\
tan majar akna ngujar ajangsul, & tidak mengeluarkan kata-kata ketus \\
Hawya majaraken ujar, mawor kroda (Vratisasana, & jangan mengucapkan kata-kata bercampur marah \\
2006$, pp. $14-30)$ & Do not say words rudely \\
& Do say only nice words \\
& not saying offensive words \\
& Do not say words in anger \\
\hline
\end{tabular}

This statement is a guidance of politeness. A polite uterance does not sound arogant and makes the speaking partner glad (Lakof, 1973, Gunawan, 1994, Chan, 2010, and Aziz, 2006).

The other values are discipline. A discipline person is a strong person, who can control himself not to break prohibition. It is written in the following part of Wratisasana.

\begin{tabular}{|l|l|}
\hline Kunang yan amangan ikang muhutaken saking ing & Kalau menyantap yang dilarang ajaran Wratisasana, \\
Wratisasana & Sang Pandita yang demikian itu, tidak dianggap pandita. \\
Panter ika sang bhujangga yan mangkana, tan & If one eat foodsprohibited by the Wratisasana teaching \\
senggahen wiku (Vratisasana, 2006, pp. $18-19)$ & Such Pandita does not consider as pandita \\
\hline
\end{tabular}

A wiku has to watch and to control his follower so that the follower does not break norms, ethics or any recognized provision. This is a responsibility of a wiku. Human being cannot be separated from responsibilities (Nashir, 2013, p. 82). This reflects in in the following Wratisasana (2006, p. 32).

\begin{tabular}{|c|c|}
\hline $\begin{array}{l}\text { Diksa mapitenget sireng sisya } \\
\text { tan kunang warah-warah } \\
\text { tan lalanakna ing sisya } \\
\text { sangkeng maryada yukti } \\
\text { hanawakya kemawih }\end{array}$ & $\begin{array}{l}\text { Guru mengingatkan siswa } \\
\text { tidak kurang mengajarkan } \\
\text { tidak membiarkan murid } \\
\text { sekehendak hatinya } \\
\text { tidak meremehkan diri pada murid } \\
\text { sebab, jika murid dibiarkan, } \\
\text { murid itu akan menyimpang } \\
\text { dari sopan santun yang benar. } \\
\text { Teacher reminds student } \\
\text { does not lack of teachings } \\
\text { does not let the student } \\
\text { does what he want as his pleases } \\
\text { does not belittle himself upon his students } \\
\text { if the student is permitted to do so, } \\
\text { the student will deviate the proper-politeness }\end{array}$ \\
\hline
\end{tabular}

Generally the Wratisasana contains important values namely 1) faithful and devotional, 2) fundamental value of life, 3) truthful, 4) affection, 5) tolerance, 6) discipline, 7) pedagogic, and 8) responsible.

\section{B. Applications of the Educational Values of Wratisasana for Character Education}

There are eight educational values in the palm manuscript Wratisasana namely 1) faithful and devotional, 2) fundamental value of life, 3) truthful, 4) affection, 5) tolerance, 6) discipline, 7) pedagogic, 8) responsible. Furthermore, the eight values are arranged in pairs to be applied into character education practice as shown in the following table.

TABLE 01:

THE APPLiCATION OF EDUCATIONAL VALUES OF WRATISASANA INTO THE CHARACTER EdUCATION PRACTICE

\begin{tabular}{|l|l|l|}
\hline No & Values of Character Education & Values of Education in the Wratisasana \\
\hline 01 & Religious & $\begin{array}{l}\text { 01. Faithful and devotional } \\
\text { 02. Fundamental value of life }\end{array}$ \\
\hline 02 & Truthful & 01. Truthful \\
\hline 03 & Tolerance & 01. Affection, 02. Tolerance \\
\hline 04 & Discipline & 01. Discipline \\
\hline 05 & Hardworking & 01. Discipline \\
\hline 06 & Friendly & 01. Affection \\
\hline 07 & Love for peace & 01. Affection, 02. Politeness \\
\hline 08 & Fond of reading & 01. Pedagogical value \\
\hline 09 & Responsible & 01. Responsible \\
\hline
\end{tabular}

\section{CONCLUSION AND SugGeSTION}

Based on the contents of the palm manuscript and the experts opinion, it can be concluded as follows:

01. Educational values, which are implied in the palm manuscript Wratisasana is: (a) affection, (b) faithful and devotional, (3) pedagogical values, (4) truthful, (5) politeness, (6) discipline, (7) responsible, (8) tolerance, (9) fundamental value of life.

02. The nine educational values found in the palm manuscript Wratisasana are applicable for Character Education Practice. 
The conclusion brings to some suggestions. Those are explained as the followings:

01 . The values in the palm manuscripts has to be presented in the front of societies so that the values are not only becoming a sacred thing that should be devoted and worshiped, but also has to be read, well-socialized, and to be explored the advantages maximally for the sake of educational needs especially for the character education.

02. Palm manuscripts is not only known by a limited society but also allowed for those who have a capability in reading the manuscripts and conducting the right applications both in the term of space and time. This manuscript ought to be socialized.

\section{REFERENCES}

[1] Abdullah, Taufik. (ed.) (2009). Islam di Indonesia. Jakarta: Tinta Mas

[2] Ahimsa Putra, Hedi Shri. (2001). Strukturalisme Levi - Strauss: Mitos dan Karya Sastra. Yogyakarta: Galang Press.

[3] Anwar Chairul (2017). Teori-Teori Pendidikan Klasik Hingga Kontemporer. Yogyakarta: Ircisod

[4] Ayer, Alfred Jules. (2006). Teori Etika Emotif Musni In Suseso Frans Magnis, Etika Abad Keduapuluh". Yogyakarta: PT Kanisius

[5] Aziz, E. Aminudin. (2006). Realisasi Pertuturan Meminta Maaf dan Berterima Kasih di Kalangan Penutur Bahasa Indonesia: Sebuah Kajian Kesantunan Berbahasa. Lungistika Vol. 13, No. 25 September 2006, pp.122-142.

[6] Bakker, S.J. J.W.M. (1981). Filsafat Kebudayaan: Sebuah Pengantar. Yogyakarta: Kanisius dan BPKN Gunung Mulia.

[7] Casson, Ronald W. (1981). Language, Culture and Cognition. New York: McMillan Publishing Co. Inc.

[8] Cassirer, Ernst. (1987). Manusia dan Kebudayaan: Sebuah Essay tentang Manusia. (trans,) by Alois A. Nugroho. Jakarta: PT Gramedia.

[9] Chaer, Abdul. (2010). Kesantunan Berbahasa. Jakarta: Rineka Cipta.

[10] Crystal, David. (1992). The Cambridge Encyclopedia of Language. Melbourne: Cambridge University Press.

[11] Darajat, Zakiah. (2005). Kepribadian Guru. Jakarta: PT. Bulan Bintang.

[12] Dhavamony, Mariasusai. (1995). Fenomenologi Agama. (translated from the original title: Phenomenology of Religion by Kelompok Studi Agama Driyarkara) Jakarta: Kanisius.

[13] Fowler, H.W. and Fowler.F.6. (ed.) (2000). The Concise Oxford Dictionary of Current English. London: Oxford University Press.

[14] Graham, Gordon. (2015) Teori-Teori Etika (translated from Eight Theories of Ethics by Irfan M. Zakkie. Bandung: Nusa Media

[15] Grixti, Joe. (2009). Pop Goes the Canon, Consumer Culture and Arstetic Value in Screen Adaptation of Literacy Clas sics In Eriropion Journal of Cultural Studies, Vol. 12 (4) pp. 447 - 467.

[16] Gunawan, Asim. (1994). Kesantunan Negatif di Kalangan Durbahasawan Indonesia-Jawa di Jakarta: Kajian Sosio Pragmatik. In PELLBA 7. pp. 81-111.

[17] Gural, Stevlana K. and Stepan A. Bayko. (2014). Analysis of Literacy Text's Conceptosphere in the Process Teaching Literacy Translation. In The XXV Annual Informational Academic Conference, Language and Culture.

[18] Halliday, M.A.K. and Ruqaiya Hasan. (1992). Language, Context and Aspect of Language. London: Edward Arnold.

[19] Hymes, Dell. H. (1972). The Etnography of Speaking In A Fishman (ed.) Reading in the Sociology of Language. Mouton Paris: the Hague.

[20] Jendra, I Wayan. (2009). Etika Berbicara Dalam Sastra Hindu (Sebuah Analisis Religiososiolinguistik). In Pemikiran Kritis Guru Besar Universitas Udayana pp. 11-35. Denpasar: Udayana University Press)

[21] Juanda. (2016). Kajian Nilai Sastra Anak Sulawesi Barat Alternatif Materi Ajar dalam Pengajaran Sastra. Prosiding Forum Ilmiah XII FPBS 2016. Bandung: FPBSUPI.

[22] Khandwa, Sadh. D.R. (1992). Linguistik di Pelbagai Budaya (transl.) Soenjono Dardjowidjojo), Jakarta: Ganaco N.V.

[23] Kesuma, Dharma, at al. (2011). Pendidikan Karakter: Kajian Teori dan Praktik di Sekolah. Bandung: PT. Remaja Rosdakarya

[24] Khotijah, Nyayu. (2016). Psikologi Pendidikan. Jakarta: PT. Raja Grafindo Persada

[25] Megawangi, Ratna. (2004). Pendidikan Karakter, Solusi yang Tepat Membangun Bangsa. Bogor: Indonesia Heritage Foundation

[26] Nashir, Haedar. (2013). Pendidikan Karakter Berbasis Agama dan Kebudayaan. Yogyakarta: Multi Presindo

[27] Lakoff, Robin. (1973). The Logic of Politeness or Minding Tour p's' and q's, in Papers from the Ninth Regional Meeting

[28] Mantra, I.B. Prof. Dr. (1997). Tata Susila Hindu Dharma. Denpasar: Upada Sastra.

[29] Moeliono, Anton. et. al. (ed.). (1988). KBBI. Jakarta : P3B Depdikbud

[30] Mustari, Mohammad. (2014). Nilai Karakter Refleksi untuk Pendidikan. Jakarta: PT Raja Grafindo Persada

[31] Mustika, Ika. (2011). Pembinaan Karakter Melalui Pembelajaran Sastra Berbasis Strategi Metakognitif dalam Kholid A. Hairas dan Ma'mer Saadie, (Eds.). Pendidikan Sastra dan Karakter Bangsa. Bandung: FPBS, UPJ.

[32] Nashir, Dr. Haerdar. (2013). Pendidikan Karakter Berbasis Agama dan Budaya. Yogyakarta: Multi Presindo.

[33] Pudja, I Gede. (1985). (trans.) Sarasamuscaya. Jakarta: Depag. R.I.

[34] Rahman, Agus Abdul. (2014). Psikologi Sosial Integrasi Pengetahuan Wahyu dan Pengetahuan Empirik. Jakarta: PT. Raja Grafindo Persada

[35] Rasna, I Wayan, et. al. (2016). Kearifan Lokal sebagai Dasar Rekonstruksi Pendidikan Karakter Melalui Buku Pelajaran Bahasa Indonesia di Kelas Rendah: Sebuah Kajian Etnopedagogi pada Siswa SD di Bali. Research Report of Penelitian Stranas Tahun Ke-2 Singaraja: Undiksha.

[36] Ruaire, G. Mac. E. Otessen, and R. Precey. (2013). Leadership for Inclusive Education, Value, Vision, and Voices. Rotterdam: Sesse Publishers.

[37] Samani, Muchlas and Hariyanto. (2012). Konsep dan Modal Pendidikan Karakter. Bandung. PT. Remaja Rosdakarya

[38] Sibarani, Robert. (2004). Antropologi Linguistik. Medan: Poda. 
[39] Soyomukti, Nurani. (2015). Teori-Teori Pendidikan dari Tradisional (Neo) Liberal, Marxis, Sosialis, hingga Postmodern. Yogyakarta: Ar - Ruzz Media

[40] Suardanaya, IB. (2006). Alih Aksara dan Alih Bahasa Lontar Wratisasana. Denpasar: Disbud Provinsi Bali

[41] Sudaryanto. (1990). Menguak Fungsi Hakiki Bahasa. Yogyakarta: Duta Wacana University Press

[42] Su'ud, Astini. (1990). Ingatan dan Pikiran. Semarang: IKIP Semarang

[43] Suryawan, Nyoman. (2017). Kearifan Lokal sebagai Modal Sosial dalam Integrasi antara Etnik Bali dan Etnik Bugis di Desa Petang, Badung, Bali in Jurnal Kajian Bali Volume 07, No. 01, April 2017. Denpasar. Pusat Kajian Bali

[44] Teeuw, A. (1984). Sastra dan Ilmu Sastra. Pengantar Teori Sastra. Jakarta: PT. Pustaka Jaya

[45] Walgito, Buno. (2011). Teori-Teori Psikologi Sosial. Yogyakarta: CV Andi Offset

[46] Waruwu. Fidelis. E. (2010). Membangun Budaya Berbasis Nilai. Yogyakarta: Kanisius

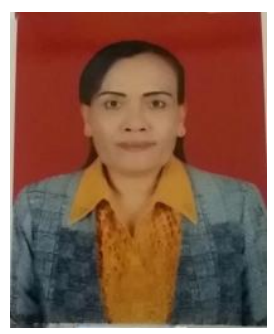

Relin D.E. M.Ag has obtained her doctorate degree in Udayana University in 2011. She was born in Banyuwangi on the 1st August 1968. She is the lecturer of Hindu Dharma Institute in Denpasar. Her interests of study are Philosophy, education, and culture. She had published several articles either in local or international journals. in 2014, she had published her articles entitled "The philosophy of Java script in cycle of life of Javanese community in modern era Discovery The International Daily. In 2015, she had published Hyper Spirituality Of Puppet In The Jawa Society In Modern Era and Philosophy of Cremation in Bali. Her recent study has been published entitled Marriage philosophy of Balinese culture.

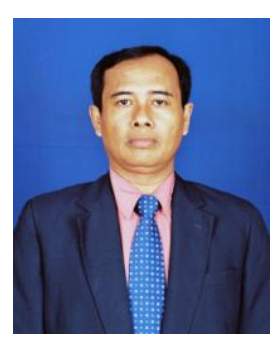

I Wayan Rasna, born $31^{\text {st }}$ December 1960, earned a Sarjana degree (Drs) in Indonesian and Indonesian Literature at Jurusan Pendidikan Bahasa dan Sastra Indonesia of FKIP Udayana University, Singaraja, Bali, Indonesia in 1983, a Magister Pendidikan degree (Master in Education) at Program Studi Pendidik-an Bahasa IKIP Bandung, Indonesia) in 1996, and a Doctor degree in Linguistics at Program Pascasarjana Udayana University, Denpasar, Bali, Indonesia in 2010. His major field of study is linguistics and culture.

He was appointed as a lecturer at FKIP Udayana University, Singaraja, Bali, Indonesia in 1984 and as Director Secretary at Program Diploma Kependidikan, and as Chairperson of Postgraduate Study of Indonesian Language at Program Pascasarjana, Universitas Pendidikan Ganesha, Singaraja, Bali, Indonesia in 2014. His works include: Harmonisasi Kearifan Lokal Nusantara dan Bali untuk Pendidikan Karakter di SD: Sebuah Analisis Etnopedagogi (Denpasar, Bali, Indonesia). In Jurnal Kajian Bali Vol 06 No. 01 April 2011; Rerajahan Kawisesan dalam Teks Ajiblegodawa Sebuah Kajian Etnosemiotika (Denpasar, Bali, Indonesia). In Jurnal Kajian Bali Vol 06.No. 01 April, 2011; Reconstruction of Local Wisdom for Character Education through the Indonesian Language Learning: An Ethnopaedagogical Methodology. UK. TPLS (Theory and Practice in Language Studies Academy Publication, UK, 2017. His interests are in Linguistics and Culture.

Prof. Rasna is a member of Masyarakat Linguistik Indonesia and chairperson of IKAPROBSI (Ikatan Program Studi Bahasa dan Sastra Indonesia) BALI

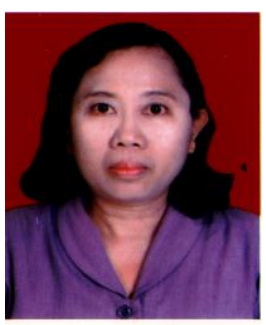

Ni Wayan Sariani Binawati, M.Ag is the lecturer of Hindu Dharma Institute in Denpasar, Bali. She was born in Denpasar $23^{\text {th }}$ of February 1964. Her research interests includes education, language and literature, and Hindu literature. She had written several international and local paper. Her study in 2015 was published in Proceeding International Seminar on Religious Manuscripts in Multiculturalism for a Better Life (Humanity and Peace) entitled Etno Pedagogic Value in The Lontar of Sang Hyang Aji Saraswati. She also has published international paper entitled Teachers Function as A Model in Character Education in 2016. 